\title{
Patch-Clamp Recordings from Lateral Line Neuromast Hair Cells of the Living Zebrafish
}

\author{
Anthony J. Ricci, ${ }^{1}$ Jun-Ping Bai, ${ }^{4}$ Lei Song, ${ }^{2}$ Caixia Lv, ${ }^{3}$ David Zenisek, ${ }^{3}$ and Joseph Santos-Sacchi ${ }^{2,3,5}$ \\ ${ }^{1}$ Departments of Otolaryngology and Molecular and Cellular Physiology, Stanford University School of Medicine, Stanford, California 94305 , and \\ Departments of ${ }^{2}$ Surgery (Otolaryngology), ${ }^{3}$ Cellular and Molecular Physiology, ${ }^{4}$ Neurology, and ${ }^{5}$ Neurobiology, Yale University School of Medicine, New \\ Haven, Connecticut 06510
}

Zebrafish are popular models for biological discovery. For investigators of the auditory and vestibular periphery, manipulations of hair cell and synaptic mechanisms have relied on inferences from extracellular recordings of physiological activity. We now provide data showing that hair cells and supporting cells of the lateral line can be directly patch-clamped, providing the first recordings of ionic channel activity, synaptic vesicle release, and gap junctional coupling in the neuromasts of living fish. Such capabilities will allow more detailed understanding of mechano-sensation of the zebrafish.

\section{Introduction}

Zebrafish hold promise for uncovering physiological mechanisms that are difficult to realize in other model species, because of the benefits of rapid reproductive rate and reduced organismal complexity (Rinkwitz et al., 2011). Indeed, progress has been enormous with this species, even in the auditory/vestibular arena, a field that usually prides itself on understanding human mechanisms with mammalian models. For example, great strides have been made in hair cell mechano-transduction and synaptic mechanisms (Nicolson, 2005). However, an obstacle to truly capitalizing on zebrafish for hair cell mechanism discovery is the heretofore inability to obtain patch-clamp recordings from neuromast sensory hair cells. We now report that this impediment has been overcome. We show preliminary data of whole-cell recordings from cells within lateral line neuromasts of living zebrafish, demonstrating ionic channel activity and synaptic vesicle release in hair cells. Additionally, we identify voltage-dependent gap junctional coupling in neuromast supporting cells. Our approach should help investigators obtain cellular data crucial to understanding the powerful genetic manipulations already available in zebrafish.

\section{Materials and Methods}

Zebrafish of either sex ranging in age from 3 to 14 days postfertilization (dpf) were anesthetized in Tricane and mounted in a recording chamber using dental floss tie downs (see Ricci and Fettiplace, 1997). Viability was monitored by visually monitoring heart rate and blood flow. An upright Nikon Eclipse was used for viewing, and recordings were made with an

Received Sept. 6, 2012; revised Dec. 12, 2012; accepted Dec. 21, 2012.

Author contributions: A.J.R., D.Z., and J.S.-S. designed research; A.J.R., J.-P.B., L.S., C.L., and J.S.-S. performed research; A.J.R. and J.S.-S. analyzed data; A.J.R. and J.S.-S. wrote the paper.

This work was supported by NIH Grants EY021195 to D.Z., DC009913 to A.J.R. and J.S.-S., P30 44992 to A.J.R., and DC000273 to J.S.-S.

Correspondence should be addressed to Joseph Santos-Sacchi, Surgery (Otolaryngology), Yale University School of Medicine, BML 224, 333 Cedar Street, New Haven, CT 06510. E-mail: joseph.santos-sacchi@yale.edu.

DOI:10.1523/JNEUROSCI.4265-12.2013

Copyright $\odot 2013$ the authors $\quad 0270-6474 / 13 / 333131-04 \$ 15.00 / 0$
Axon 200B amplifier with an Axon DD1322 digitizer. Images were enhanced with a Hamamatsu CCD camera. All recordings and image capture were made with jClamp software (Scisoft). Cells were held at -80 $\mathrm{mV}$. Extracellular solution was as follows (in $\mathrm{mM}$ ): $125 \mathrm{NaCl}, 1.0 \mathrm{KCl}, 2.2$ $\mathrm{MgCl}_{2}, 2.8 \mathrm{CaCl}_{2}, 10$ HEPES, 6 D-glucose, 285 mOsm, pH 7.6. Pipette solution was (in mM): $90 \mathrm{CsCl}, 20 \mathrm{TEA}, 5 \mathrm{Na}_{2} \mathrm{ATP}, 3.5 \mathrm{MgCl}_{2}, 10 \mathrm{HEPES}$, 1 EGTA, 260 mOsm, pH 7.2. Intracellular $\mathrm{KCl}(110 \mathrm{~mm})$ solution lacked TEA. $\mathrm{P} /-5$ protocols were made at a subtraction holding potential of -80 $\mathrm{mV}$. Pipette resistance was typically $6.5 \mathrm{M} \Omega$ with $\mathrm{Cs}$ pipette solutions. Pipettes used to clean a pathway toward hair cells were $\sim 1-2 \mathrm{M} \Omega$. For patch pipettes, 1.5-mm-thick-walled borosilicate glass was used without any coating. Capacitance measures were made with a dual sine admittance technique (Santos-Sacchi, 2004; Schnee et al., 2011a,b). Recordings were made at room temperature. Data are reported as mean $\pm \mathrm{SE}$.

\section{Results}

Zebrafish lateral line neuromasts are peripherally located on each side of the zebrafish. Before scale formation, the organ is accessible via micropipette. Figure 1 shows a series of Hoffman optics images at different levels through the neuromast, starting apically where the hair cell kinocilia insert into the gelatinous cupola $(A, B)$. Each kinocilium arises from one hair cell, and can be used to count the number of hair cells in the neuromast. In this example, 17 hair cells are present. Further medial, the outlines of the supporting cell boundaries ( $C, D$; arrows) are visible. In the center of the neuromast, the tear drop-shaped hair cells are visible $(E$; arrows). To prepare for patch clamping, the supporting cells at the neuromast periphery must be breeched by suction from a large-tipped pipette, whereupon entry into the neuromast is confirmed by positive pressure expanding the neuromast extracellular volume ( $F-H$; arrows depict fluid-filled space). By maneuvering a patch pipette under positive pressure through the path previously made, a hair cell can be patched $(I)$. This approach has been used to record from hair cells in a variety of hair cell organs (Ricci and Fettiplace, 1997; Ricci et al., 2005). We have recorded from $>10$ neuromasts on several fish. Gigohm seals were readily obtained. With Cs pipette solutions, average membrane capacitance $\left(C_{\mathrm{m}}\right)$ of hair cells determined from transient analysis at $-80 \mathrm{mV}$ at the 
beginning of recording was $1.6 \pm 0.09 \mathrm{pF}$ $(n=5)$. Usually, $1-2$ hair cells were recorded during a day's work.

Figure 2 shows $\mathrm{K}$ currents recorded from a patched hair cell with a K-based intracellular solution. Raw currents were evoked with voltage steps $(C)$ following a prepulse to $-120 \mathrm{mV}$ from a holding potential of $-80 \mathrm{mV}$. The outward currents were composed of at least two components, a fast decaying one and a slower noninactivating one $(A)$. The fastinactivating (A-type) current was removed with a prepulse to $-40 \mathrm{mV}(B)$, and by subtraction (traces $A$ minus $B$ ), the transient current was isolated $(D)$. Figure $2 E$ shows an average $I-V$ curve of unsubtracted currents collected from a $-80 \mathrm{mV}$ holding potential, illustrating outward rectification averaging $0.25 \pm 0.07 \mathrm{nA}$ at $+10 \mathrm{mV}(n=3)$. Slope resistance between -120 and $-60 \mathrm{mV}$ was $\sim 2 \mathrm{G} \Omega$. Using Cs solutions and $\mathrm{P} / \mathrm{N}$ leakage subtraction, we also identified an inward $\mathrm{Ca}^{2+}$ current (Fig. 2F). The current was small and noninactivating during voltage steps. At $-10 \mathrm{mV}$ the Ca current averaged $0.018 \pm 0.003 \mathrm{nA}(n=5)$. Ca influx is expected to release synaptic vesicles at the basal pole of hair cells. Figure $2 G$ illustrates the release of vesicles, measured as a membrane capacitance increase. In this case, during the course of a $3 \mathrm{~s}$ depolarization to $-10 \mathrm{mV}, C_{\mathrm{m}}$ increased $\sim 40 \mathrm{fF}$. Open circles depict average responses. The average increase in $C_{\mathrm{m}}$ at $3 \mathrm{~s}$ under these conditions was $52 \pm 23 \mathrm{fF}(n=3$; initial $C_{\mathrm{m}}$ was $\left.1.37 \pm 0.15 \mathrm{pF}\right)$. Assuming a vesicle capacitance of $38-50 \mathrm{aF}$ (Schnee et al., 2005; Graydon et al., 2011), the $C_{\mathrm{m}}$ increase equates to a surface area equivalent to $1040-1370$ vesicles. This release is greater than estimates of vesicles associated with synaptic ribbons (2-5 ribbons possessing $\sim 120$ vesicles each; Obholzer et al., 2008; Trapani and Nicolson, 2011), which predicts 12-30 fF for vesicles of 50 aF size. The larger measured values indicate recruitment of non-ribbon-associated vesicles, though not nearly at the rate observed in turtle or rat (Schnee et al., 2011a,b). We also tested for transduction currents during whole-cell voltage clamp by displacing the cupola sinusoidally with a fluid jet delivered by a puff pipette $(n=4)$ (Fig. 3$)$. Currents of $\sim 100 \mathrm{pA}$ were evoked in this cell of $\sim 1.3$ $\mathrm{G} \Omega$ input impedance. A decrease in amplitude during the extent of stimulation resembles adaptation. It should be noted that the Tricane anesthetic that we used is expected to reduce MET function (Farris et al., 2004).

Finally, we observed cells that had larger than the average 1.6 $\mathrm{pF}$ capacitance of hair cells, which we identify as supporting cells $(n=4)$. Auditory support cells are known to be joined into a
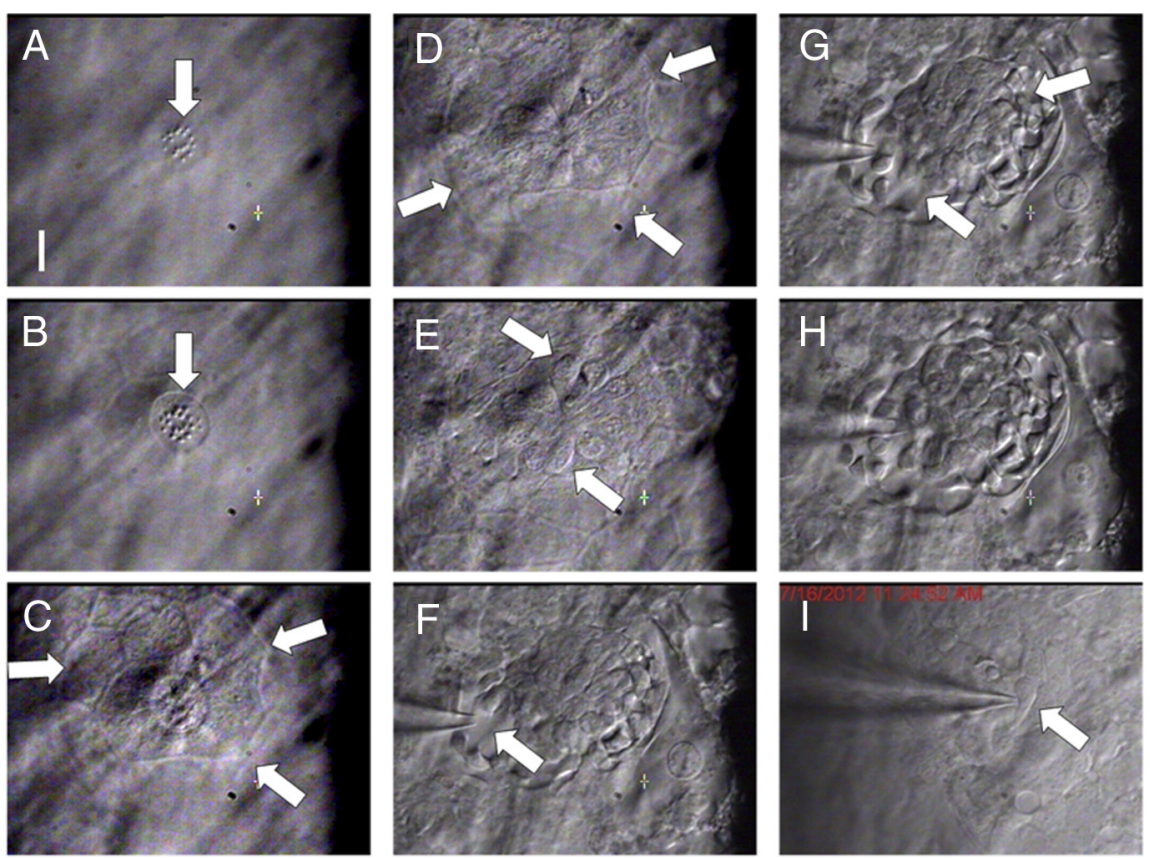

Figure 1. Electrode approach for patch clamping zebrafish hair cells. Zebrafish were anesthetized and fixed laterally onto a recording chamber. $\boldsymbol{A}-\boldsymbol{E}$, Images show neuromast structure from cupola/kinocilia top $(\boldsymbol{A})$ to location of hair cell soma $(\boldsymbol{E})$. See Results for details. $\boldsymbol{F}$-I, Outer supporting cell ring is breeched with large suction electrode, providing a path for patch electrode to seal on hair cell. See Results for details. Scale bar $(\boldsymbol{A}), 8 \boldsymbol{\mu m}$. Images from $7 \mathrm{dpf}$.
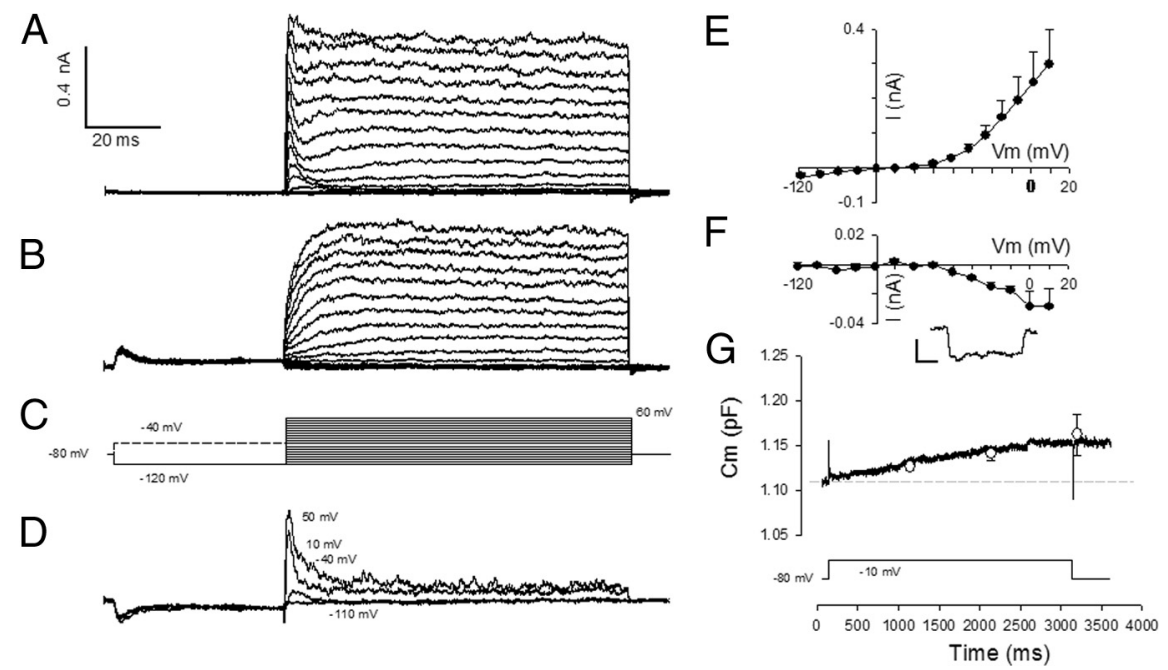

Figure 2. $\mathrm{K}$, Ca currents and synaptic vesicle release from hair cells in living zebrafish. $A$, Outward $\mathrm{K}$ currents induced by voltage steps from prepulse level $(-120 \mathrm{mV})$ to a range of voltages depicted in $\boldsymbol{C} . \boldsymbol{B}, \mathrm{K}$ currents generated following prepulse to $-40 \mathrm{mV}$. $\boldsymbol{D}$, Subtraction of traces ( $\boldsymbol{A}$ minus $\boldsymbol{B}$ ) reveals A-type inactivating current. $\boldsymbol{E}$, Outward currents without leakage subtraction. Average $I-V(+S E ; n=3)$ of last $20 \mathrm{~ms}$ of $100 \mathrm{~ms}$ current traces. $\boldsymbol{F}$, Inward Ca current is revealed with P/-5 leakage subtraction protocol collected with Cs pipette solution. Average $\mathrm{I}-V(+\mathrm{SE} ; n=5)$ of last $10 \mathrm{~ms}$ of $50 \mathrm{~ms}$ current traces. Inset, Noninactivating Ca current trace, generated in response to $-30 \mathrm{mV}$ step from $-80 \mathrm{mV}$ holding potential. Scale is $6 \mathrm{pA} / 10 \mathrm{~ms}$. G, Hair cell synaptic vesicle release was determined with membrane capacitance measures. The cell was held at $-80 \mathrm{mV}$ and stepped to $-10 \mathrm{mV}$ for $3 \mathrm{~s}$; vesicle release is evident from increase in $C_{m}: \delta C_{m}$ is $\sim 40 \mathrm{fF}$ (dark traces). Endocytosis was not observed in our experimental time frame. Dotted lines show initial capacitance level. Open circles indicate average ( \pm SE) responses at $1(n=5), 2(n=3)$, and 3 $(n=3)$ s following the onset of depolarization. Data were obtained at 7-12 dpf.

syncytium and display large capacitances (Santos-Sacchi, 1991). Figure 4 illustrates supporting cell recordings where voltage was ramped to voltage extremes of $\sim \pm 90 \mathrm{mV}$. Capacitance, in this case calculated from transient current response to step voltages, varied according to holding potential (Fig. $4 A$ ). In fact, there is the expected reciprocal relationship between input resistance and 


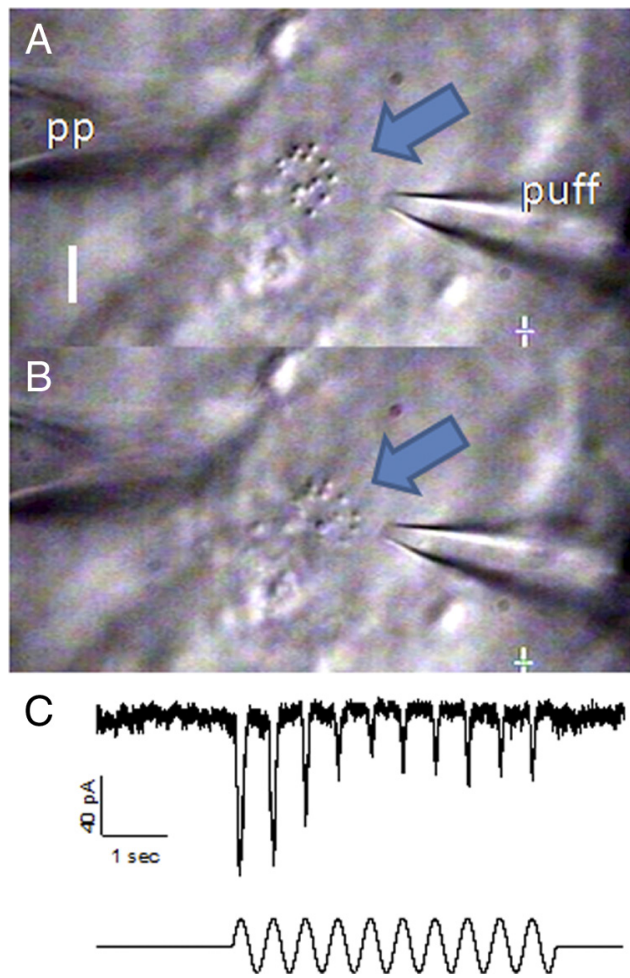

Figure 3. MET current activity during cupola deflection. $\boldsymbol{A}, \mathrm{A}$ patch pipette (pp) voltageclamped one hair cell in the neuromast, while a puff pipette (puff) was used to stimulate the kinocilia-embedded cupola. $\boldsymbol{B}$, Suction phase of cupola stimulation showing kinocilia displaced closer to puff pipette. $\boldsymbol{C}$, Receptor currents generated by sinusoidal fluid jet activity. Stimulus voltage driving the water jet is shown beneath currents. With the solutions we used, rectification of the response is expected (Farris et al., 2004). Scale bar, $6 \mu \mathrm{m}$. Data were obtained at dpf 7. Stimulus frequency was $2.0 \mathrm{~Hz}$.

capacitance as gap junctions uncouple and recouple during depolarization and hyperpolarization, respectively (Fig. 4B). Auditory supporting cells possess voltage-dependent gap junctions (Zhao and Santos-Sacchi, 2000) and exhibit this type of behavior, as well.

\section{Discussion}

The zebrafish is a powerful model for auditory/vestibular research. Here we provide data demonstrating the feasibility of patch recording hair cells and supporting cells in lateral line neuromasts from the living zebrafish. The approach is similar to the one we have used to record from a variety of auditory/vestibular end organs (Ricci et al., 2005; Schnee et al., 2011a), and should allow direct assessment of hair cell function in the multitude of existing genetic manipulations available in the zebrafish.

Zebrafish hair cells possess outward $\mathrm{K}$ currents, and inward Ca currents similarly found in other auditory/vestibular-like organs. For example, the component K currents presented here are similar to those in the frog vestibular hair cell, where depolarizing prepulse was found to dissociate A-type and delayed rectifiertype contributions (Norris et al., 1992). Indeed, the basolateral electrical properties measured in the zebrafish hair cells are quite similar to those measured in bird (Lang and Correia, 1989; Ricci and Correia, 1999), frog (Norris et al., 1992; Masetto et al., 1994), turtle (Brichta et al., 2002), and mammal (Eatock and Hutzler, 1992). Though the zebrafish hair cell Ca current is small, its properties are similar to those of $\mathrm{CaV}$ (1.3) identified in zebrafish (Sidi et al., 2004) and its magnitude is similar to that of other vestibular hair cell types including those of frog (Prigioni et al., 1992;
A

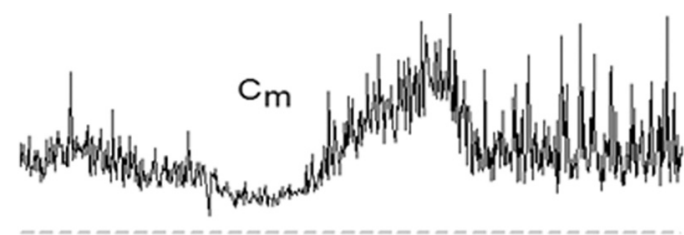

$\mathrm{B}$
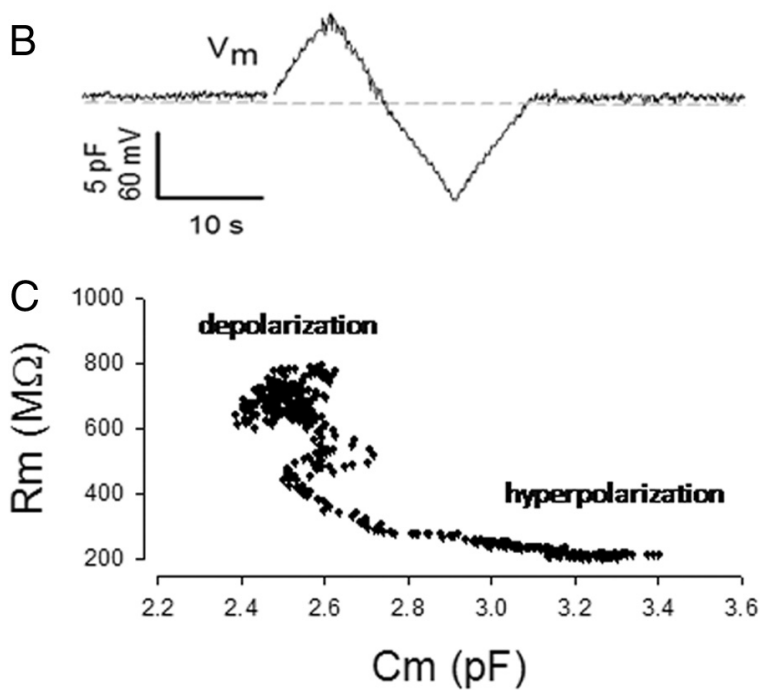

Figure 4. Input capacitance and resistance of supporting cell syncytium. $\boldsymbol{A}, \boldsymbol{B}$, An individual supporting cell was patch-clamped $(\boldsymbol{A})$ and the membrane voltage modulated with a slow ramp to $\sim \pm 90 \mathrm{mV}(\boldsymbol{B})$. Note slow changes in input capacitance corresponding to membrane voltage, indicative of voltage-dependent gap junctional coupling found in the organ of Corti. Input capacitance indicates that several cells contribute to membrane surface area. Dotted lines indicate zero levels. Data were obtained at $12 \mathrm{dpf}$. $\boldsymbol{C}$, In another cell, the reciprocal relationship between input resistance and capacitance as gap junctions uncouple and recouple during depolarization and hyperpolarization, respectively, is shown. Data were obtained at $3 \mathrm{dpf}$.

Martini et al., 2000), chick (Ohmori, 1984), and rat (Bao et al., 2003). Very recently, dissociated inner ear hair cells of the zebrafish were successfully recorded, and the reported K current was similar to that reported here (Einarsson et al., 2012).

The calcium current elicited was sufficient to evoke substantial transmitter release, indicative of vesicle replenishment from pools remote to the synaptic ribbon. The apparent absence of a superlinear vesicular release component that is found in auditory hair cells of turtle, mouse, and rat (Schnee et al., 2011a,b), and which may be associated with a release of intracellular stored $\mathrm{Ca}$, might underscore differences in functional requirements for vesicle recruitment mechanisms in zebrafish hair cells. Perhaps this difference relates to auditory versus vestibular hair cell properties, although calcium-induced calcium release has been observed in frog vestibular hair cells (Lelli et al., 2003); alternatively, the very small volume of zebrafish hair cells may not require elaborate vesicle recruitment mechanisms, or the small volume may make a kinetic separation between release components more difficult to observe. Finally, in contrast to observations in some other species (Schnee et al., 2005; Graydon et al., 2011), the substantial vesicle release arising from such small Ca currents may indicate efficient synaptic mechanisms. Of course, the preliminary data we report here require further investigation. Nevertheless, one of the main benefits of recordings in the zebrafish hair cell will be to capitalize on the wealth of tools and genetic manipulations available for the ribbon synapse (Nicolson, 2005; Francis et al., 2011) in a preparation that we now show to be readily accessible.

Aside from direct investigations on sensory hair cell mechanisms, the neuromast provides an opportunity to understand supporting cell roles in sensory transduction. In the organ of 
Corti, electrical coupling has been proposed to sink K away from active hair cells, thereby preserving indefatigable hair cell function (Santos-Sacchi, 1985, 2000). Our observation of similar voltage-dependent gap junctional coupling in zebrafish neuromasts indicates a corresponding role in this simple organ, with the preparation offering model benefits similar to those for hair cell study.

\section{References}

Bao H, Wong WH, Goldberg JM, Eatock RA (2003) Voltage-gated calcium channel currents in type I and type II hair cells isolated from the rat crista. J Neurophysiol 90:155-164. CrossRef Medline

Brichta AM, Aubert A, Eatock RA, Goldberg JM (2002) Regional analysis of whole cell currents from hair cells of the turtle posterior crista. J Neurophysiol 88:3259-3278. CrossRef Medline

Eatock RA, Hutzler MJ (1992) Ionic currents of mammalian vestibular hair cells. Ann N Y Acad Sci 656:58-74. CrossRef Medline

Einarsson R, Haden M, Diciolli G, Lim A, Mah-Ginn K, Aguilar K, Yazejian L, Yazejian B (2012) Patch clamp recordings in inner ear hair cells isolated from zebrafish. J Vis Exp 68:e4281.

Farris HE, LeBlanc CL, Goswami J, Ricci AJ (2004) Probing the pore of the auditory hair cell mechanotransducer channel in turtle. J Physiol 558: 769-792. CrossRef Medline

Francis AA, Mehta B, Zenisek D (2011) Development of new peptide-based tools for studying synaptic ribbon function. J Neurophysiol 106:1028-1037. CrossRef Medline

Graydon CW, Cho S, Li GL, Kachar B, von Gersdorff H (2011) Sharp Ca ${ }^{2+}$ nanodomains beneath the ribbon promote highly synchronous multivesicular release at hair cell synapses. J Neurosci 31:16637-16650. CrossRef Medline

Lang DG, Correia MJ (1989) Studies of solitary semicircular canal hair cells in the adult pigeon. II. Voltage-dependent ionic conductances. J Neurophysiol 62:935-945. Medline

Lelli A, Perin P, Martini M, Ciubotaru CD, Prigioni I, Valli P, Rossi ML, Mammano F (2003) Presynaptic calcium stores modulate afferent release in vestibular hair cells. J Neurosci 23:6894-6903. Medline

Martini M, Rossi ML, Rubbini G, Rispoli G (2000) Calcium currents in hair cells isolated from semicircular canals of the frog. Biophys J 78: 1240-1254. CrossRef Medline

Masetto S, Russo G, Prigioni I (1994) Differential expression of potassium currents by hair cells in thin slices of frog crista ampullaris. J Neurophysiol 72:443-455. Medline

Nicolson T (2005) The genetics of hearing and balance in zebrafish. Annu Rev Genet 39:9-22. CrossRef Medline

Norris CH, Ricci AJ, Housley GD, Guth PS (1992) The inactivating potassium currents of hair cells isolated from the crista ampullaris of the frog. J Neurophysiol 68:1642-1653. Medline

Obholzer N, Wolfson S, Trapani JG, Mo W, Nechiporuk A, Busch-Nentwich E, Seiler C, Sidi S, Söllner C, Duncan RN, Boehland A, Nicolson T (2008)
Vesicular glutamate transporter 3 is required for synaptic transmission in zebrafish hair cells. J Neurosci 28:2110-2118. CrossRef Medline

Ohmori H (1984) Studies of ionic currents in the isolated vestibular hair cell of the chick. J Physiol 350:561-581. Medline

Prigioni I, Masetto S, Russo G, Taglietti V (1992) Calcium currents in solitary hair cells isolated from frog crista ampullaris. J Vestib Res 2:31-39. Medline

Ricci AJ, Correia MJ (1999) Electrical response properties of avian lagena type II hair cells: a model system for vestibular filtering. Am J Physiol 276:R943-R953. Medline

Ricci AJ, Fettiplace R (1997) The effects of calcium buffering and cyclic AMP on mechano-electrical transduction in turtle auditory hair cells. J Physiol 501:111-124. CrossRef Medline

Ricci AJ, Kennedy HJ, Crawford AC, Fettiplace R (2005) The transduction channel filter in auditory hair cells. J Neurosci 25:7831-7839. CrossRef Medline

Rinkwitz S, Mourrain P, Becker TS (2011) Zebrafish: an integrative system for neurogenomics and neurosciences. Prog Neurobiol 93:231-243. CrossRef Medline

Santos-Sacchi J (1985) The effects of cytoplasmic acidification upon electrical coupling in the organ of Corti. Hear Res 19:207-215. CrossRef Medline

Santos-Sacchi J (1991) Isolated supporting cells from the organ of Corti: some whole cell electrical characteristics and estimates of gap junctional conductance. Hear Res 52:89-98. CrossRef Medline

Santos-Sacchi J (2000) Cell coupling in Corti's organ. Brain Res Brain Res Rev 32:167-171. Medline

Santos-Sacchi J (2004) Determination of cell capacitance using the exact empirical solution of $\mathrm{dY} / \mathrm{dCm}$ and its phase angle. Biophys J 87:714-727. CrossRef Medline

Schnee ME, Lawton DM, Furness DN, Benke TA, Ricci AJ (2005) Auditory hair cell-afferent fiber synapses are specialized to operate at their best frequencies. Neuron 47:243-254. CrossRef Medline

Schnee ME, Santos-Sacchi J, Castellano-Muñoz M, Kong JH, Ricci AJ (2011a) Calcium-dependent synaptic vesicle trafficking underlies indefatigable release at the hair cell afferent fiber synapse. Neuron 70:326-338. CrossRef Medline

Schnee ME, Castellano-Muñoz M, Kong JH, Santos-Sacchi J, Ricci AJ (2011b) Tracking vesicle fusion from hair cell ribbon synapses using a high frequency, dual sine wave stimulus paradigm. Commun Integr Biol 4:785-787. Medline

Sidi S, Busch-Nentwich E, Friedrich R, Schoenberger U, Nicolson T (2004) gemini encodes a zebrafish L-type calcium channel that localizes at sensory hair cell ribbon synapses. J Neurosci 24:4213-4223. CrossRef Medline

Trapani JG, Nicolson T (2011) Mechanism of spontaneous activity in afferent neurons of the zebrafish lateral-line organ. J Neurosci 31:1614-1623. CrossRef Medline

Zhao HB, Santos-Sacchi J (2000) Voltage gating of gap junctions in cochlear supporting cells: evidence for nonhomotypic channels. J Membr Biol 175:17-24. CrossRef Medline 